\title{
Elections and Ethnic Civil War
}

Comparative Political Studies 46(3) 387-417

(C) The Author(s) 2012

Reprints and permission: sagepub.com/journalsPermissions.nav DOI: I0.1 I77/00 I04|40I 2453697 http://cps.sagepub.com

@SAGE

\section{Lars-Erik Cederman', Kristian Skrede Gleditsch ${ }^{2}$, and Simon $\mathrm{Hug}^{3}$}

\begin{abstract}
Existing research on how democratization may influence the risk of civil war tends to consider only changes in the overall level of democracy and rarely examines explicitly the postulated mechanisms relating democratization to incentives for violence. The authors argue that typically highlighted key mechanisms imply that elections should be especially likely to affect ethnic groups' inclination to resort to violence. Distinguishing between types of conflict and the order of competitive elections, the authors find that ethnic civil wars are more likely to erupt after competitive elections, especially after first and second elections following periods of no polling. When disaggregating to the level of individual ethnic groups and conflicts over territory or government, the authors find some support for the notion that ethno-nationalist mobilization and sore-loser effects provoke postelectoral violence. More specifically, although large groups in general are more likely to engage in governmental conflicts, they are especially likely to do so after noncompetitive elections. Competitive elections, however, strongly reduce the risk of conflict.
\end{abstract}

\section{Keywords}

civil war, democratization, elections, ethnic conflict

\footnotetext{
'ETH Zurich, Zurich, Switzerland

${ }^{2}$ University of Essex, Colchester, UK \& Peace Research Institute Oslo, Norway

${ }^{3}$ University of Geneva, Geneva, Switzerland
}

\section{Corresponding Author:}

Lars-Erik Cederman, CIS, ETH Zurich, Haldeneggsteig 4, Zurich, 8092, Switzerland

Email: Icederman@ethz.ch 
Following up earlier studies on democratization and the risk of interstate wars (e.g., Mansfield \& Snyder, 1995; Ward \& Gleditsch, 1998), recent research examines how regime transitions and changes toward greater democracy affect the likelihood of civil wars (e.g., Cederman, Hug, \& Krebs, 2010; Gleditsch, 2002; Mansfield \& Snyder, 2007a). There is a clear motivation for doing so as many of the suggested causal links between democratization and interstate wars seem to apply equally well to incentives for civil wars (Mann, 2005; Mansfield \& Snyder, 1995, 2005). More specifically, Mansfield and Snyder's (1995) main argument relies on the diversionary incentives of elites facing pressures for political reform, whereas Mann's (2005) reasoning is largely based on how ethnic cleansing and nepotism may arise when democratization forces leaders to be more dependent on securing popular support.

Much research suggests that democratization may affect the risk of conflict between states, stressing the potential tension of arguments about dangers arising from democratization with the so-called "democratic peace" or absence of war between democracies. However, the case studies discussed in greater detail by Snyder (2000) and Mann (2005) include many examples of civil wars or conflict within countries. ${ }^{1}$ More recently, some studies have pointed to how democratization and competitive elections can increase the risk of conflict within countries. For example, Collier (2009) argues that elections in "dangerous places," or states that already have a high prior likelihood of conflict, often appear to precede the outbreak of violence (also see Collier, Hoeffler, \& Söderbom, 2008).

Although at least three existing studies have modeled the possible effects of democratization on civil war in their empirical specification (e.g., Cederman, Hug, et al., 2010; Gleditsch, 2002; Mansfield \& Snyder, 2007a), there have been few explicit tests of the specific causal mechanisms postulated in this line of research. ${ }^{2}$ In this article, we examine the effect of one specific causal factor related to various potentially conflict-inducing mechanisms, namely, the holding of elections and how elections can shape incentives to resort to violence. Although democratic governance is clearly about much more than elections alone, competitive elections play a central role in almost all definitions of democracy (for prominent examples, see Alvarez, Cheibub, Limongi, \& Przeworski, 1996; Dahl, 1989, 1998; Karl, 1990; Manin, 1997; Schumpeter, 1942). Thus, in any case of a transition from an autocratic to a democratic regime, elections must be held at some point. ${ }^{3}$ To quote Bratton (1998), "While you can have elections without democracy, you cannot have democracy without elections" (p. 52).

Whether these elections are conflict prone is also of considerable practical relevance. Elections must be scheduled at some point in postconflict and/or 
democratization periods, but there is considerable debate over the alleged advantages of early versus delayed elections. Our empirical results provide new findings that can help advance this debate. We show that ethnic groups with particular characteristics are more likely to engage in conflict after an election. More specifically, after competitive elections smaller ethnic groups are more likely to engage in territorial conflicts, whereas after both competitive and noncompetitive elections, larger groups are more likely to start a conflict seeking to replace the central government. As these groups are systematically excluded from government, our results provide policy-relevant insights.

In the next section, we offer a brief discussion of the existing literature suggesting that democratization may increase the risk of civil conflict. We seek to move beyond the existing literature by examining more specifically how elections may influence the probability of conflict and assessing the specific mechanisms. We first provide a statistical test of our arguments at the country level, similar to previous empirical research relating democratization to conflict. We then proceed to additional disaggregated tests, where we distinguish between the specific actors that may engage in violence in response to elections, relying on the new data set on ethnic power relations, and we consider different types of civil war in terms of the insurgent objectives.

\section{Democratization, Elections, and Varieties of Civil Conflict}

In this brief and selective overview, we start by considering democratization processes in broader terms and their possible relationship to conflict before turning to how incentives related to elections could give rise to conflict. Although the link between democratization and domestic violence is not necessarily limited to conflicts that involve ethnically distinct antagonists (see, e.g., Huntington, 1968; Przeworski, 1991), many civil wars clearly involve an ethnic element, and much of the recent work on how democratization may cause internal conflict focuses specifically on ethnically diverse and polarized societies. This literature builds directly on classical studies that postulate that ethnic politics will have a destabilizing influence on democratic institutions (Horowitz, 1985; Rabushka \& Shepsle, 1972).

Two main conflict-inducing mechanisms have been highlighted in the more recent research on democratization and conflict. First, democratization is often linked to attempts by political entrepreneurs to make the demos coincide with a given ethnos. Hence, such actors resort to ethnic cleansing and other forms of active discrimination, intimidation, and nepotism to ensure that the state serves the interest of particular ethnic groups (Mann, 2005). 
Ethnicity tends to become much more salient in a more competitive political environment than in a closed political system, where politics is less dependent on patronage and popular support. Collier (2009, p. 70), for example, argues that the Kenyan opposition leader Raila Odinga in 2007 ran on a platform that in practice amounted to ethnic cleansing against the dominant ethnic group, the Kikuyus, who formed the main support base for the incumbent leader Mwai Kibaki. Moreover, public goods provision and access to state resources are often politically contentious issues in early phases of democratization in ethnically segmented societies (see, e.g., Breton, 1964).

Second, the need to hold on to political power may lead incumbent leaders to "play the ethnic card" and incite hostility toward other groups under increasing political competitiveness. Mansfield and Snyder (1995), for example, argue that

democratizing states are war-prone not because war is popular with the mass public, but because domestic pressures create incentives for elites to drum up nationalist sentiment. . . . Elites need to gain mass allies to defend their weakened positions ... [and] often use appeals to nationalism to stay astride their unmanageable political actions. . . . Democratization creates a wider spectrum of politically significant groups with diverse and incompatible interests. ... [W] here political parties and representative institutions are still in their infancy, the diversity of interests may make political coalitions difficult to maintain. Often the solution is a belligerent nationalist coalition. (pp. 88-89)

The principal mechanisms behind these arguments imply (a) that ethnic affiliation often dominates other cleavages in postauthoritarian political environments and (b) that elites can strengthen their core support by raising tension with, or attacking, other groups. Since elites need to mobilize supporters to win elections, diversionary conflict - whether directed against other states or ethnic groups - arises as a consequence of mobilization efforts by elites emphasizing group differences and allegiances. As opposition groups often also engage in similar behavior, many observers point to the strong risk of ethnic outbidding in political mobilization in the wake of autocratic rule where popular support has played a minor role (Rabushka \& Shepsle, 1972). ${ }^{4}$ The example provided by Collier (2009, pp. 68-75) of the Kenyan opposition leader Raila Odinga discussed above illustrates this point quite clearly.

The above arguments are implicitly linked to the role of elections as a factor and specific event that may exacerbate the risk of conflict (see Strand, 2007). Mann (2005) argues that the demos is often defined in narrow terms, 
resulting in the exclusion of other ethnic groups. In fact, the process of democratization may provoke active attempts of exclusion or intimidation, and such efforts often take on violent forms. Politicians running on exclusivist ethnic platforms typically try to prevent members of other ethnic groups from participating in elections, either on formal grounds or by undermining their ability to perform well in elections. Mansfield and Snyder's (1995) argument about ethnic outbidding highlights how such political mobilization strategies may lead to the use of violence in election campaigns.

Moreover, violence may arise over the outcome of elections, either because of actual or perceived irregularities or if some contenders reject the official election results. Przeworski (1991) argues that democracy is not established as long as the losers of elections are not ready to accept defeat. Building on this insight, Strand $(2005,2007)$ relates elections to violence and finds that elections in incomplete democracies increase the likelihood of conflict breaking out. In addition, based on a game-theoretical model, he argues that second elections after a longer period without elections are especially critical (Strand, 2007; also see Bratton, 1998) Focusing on competitive elections in developed countries, Anderson and Mendes (2005) explore the link between electoral losses and protest behavior and find that political minorities in new democracies are more prone to resort to violence after elections. Likewise, Collier (2009) highlights how "sore losers" in elections often may instigate violence after elections. ${ }^{5}$ These mechanisms can obviously apply to both ethnic and nonethnic conflicts. However, the ethnic affiliation of individuals is usually much simpler to establish than other political allegiances, which in turn makes it easier to target opponents in the aftermath of contested elections. The first and second rounds of the competitive presidential elections that took place in the Ivory Coast in the fall of 2010 provide good topical examples here. The challenger, Alassane Outtara, was credited with a narrow lead over the incumbent, Laurent Gbagbo. However, unwilling to accept his defeat, and with the help of the Constitutional Council, the incumbent president Gbagbo held on to power, thus triggering ethnic tensions and violent conflict ("Ivory Coast Election," 2010).

More generally, Collier (2009) argues that elections will only help ensure peaceful competition over political power if the rule of law is credibly guaranteed. When it is not, conflict becomes more likely since electoral outcomes are unlikely to be accepted by the losing parties (also see Strand, 2007). Mansfield and Snyder (2007b) make similar arguments in favor of "sequencing" democratization and recommend that elections should be postponed until countries have reached a sufficient threshold of internal stability and capacity for democracy (also see Brancati \& Snyder, 2010, in press). 
However, these claims are not uncontroversial, and delaying elections until countries are sufficiently stable in the aftermath of political turmoil may be neither feasible nor necessary (Carothers, 2007). Other scholars have challenged such a negative view of the dangers of "premature" democratization on empirical grounds. Birnir (2007) comes to the opposite conclusion, namely, that the first democratically held elections actually tend to stabilize ethnic politics. Her findings indicate that, in the long run, such a stabilizing effect may be sustained through inclusive representation of all ethnic groups in the legislative and executive process. Lindberg's (2009) work on elections in Africa advances a related argument, namely, that repeated elections contribute to successful transitions. Cheibub and Hays (2009) argue that elections may be a response to anticipated conflict. They argue that elections often can succeed in preventing violent conflict in democratizing regimes and suggest that the empirical evidence is consistent with this claim once the potential endogeneity is taken into account.

Previous research is somewhat inconclusive, in part because of different conceptualizations of regime change, in terms of both timing (i.e., whether to assess short-term vs. long-term changes) and type - that is, whether to focus on "large" changes between regime types or to consider changes across a continuum, including smaller changes in degree of political competitiveness that may leave institutions short of the minimum threshold for democratic practices. Based on an explicit measure of regime-type change, Cederman, Hug, et al. (2010) show that democratization periods appear to be more conflict prone than other periods. Their analysis, however, does not allow for a precise assessment of the causal mechanisms underlying the observed relationship, given its aggregated nature and focus on periods rather than specific actors and events.

\section{Deriving Theoretical Hypotheses}

In this study, we focus on causal mechanisms linked to elections as a way to render the analysis more precise than in previous work based on more sweeping measures of regime type.

As we have argued above, some mechanisms linking elections to violence are potentially of a general nature and may apply to all political actors (e.g., the sore-loser effect), whereas others apply only to ethnic conflicts (e.g., competitive ethnic mobilization). Overall, we believe that it is far more likely that the mechanisms will generate a higher risk of ethnic conflict and much less likely that elections should yield an increased risk of nonethnic conflict. Sore losers are often, although not always, linked to former combatants in previous civil 
wars, and thus taking up arms after electoral defeat reignites ethnic civil wars (see, e.g., Collier, 2009; Höglund, Jarstad, \& Söderberg Kovacs, 2009). The elections in the Ivory Coast of 2010 provide a good example, as the two competing candidates come from different parts of the country and different ethnic groups. More specifically, the Constitutional Council invalidated mostly votes in northern Muslim electoral districts and thus provided an advantage to the incumbent, who enjoyed more support in the Christian southern part of the country ("Ivory Coast Election," 2010). In light of this, we can state our expectations about the effects of elections as the following hypothesis:

Hypothesis 1 (H1): The likelihood of civil war increases after elections, and this increase is highest for ethnic wars.

Elections, however, come in different shapes and forms and are held not only in democratic (or democratizing) regimes but also in autocracies (e.g., Levitsky \& Way, 2002; Lust-Okar, 2006). Hyde and Marinov (2010) convincingly argue that different types of elections can have quite distinct wider consequences. Partly drawing on their work and Birnir's (2007) study of ethnic mobilization, we also expect that the causal mechanisms linking elections to conflict will operate differently depending on the nature of the elections. For instance, the sore-loser mechanism advanced both by Przeworski (1991) and Collier (2009) should apply only in competitive settings, that is, in elections where multiple candidates run for the same elected position. Note that these arguments are relevant regardless of whether the conflict is ethnic or nonethnic. Lindberg (2009, pp. 94-95), for instance, discusses the elections in Ethiopia of 1995 and notes that despite a partial boycott, none of the losing parties accepted the results (p. 180). Territorial conflicts broke out in 1996 and seem closely related to the prior elections. This reasoning leads us to the following hypothesis: ${ }^{6}$

Hypothesis 2a (H2a): Competitive elections increase the likelihood of both ethnic and nonethnic civil war.

In noncompetitive elections, by definition, the sore-loser mechanism cannot apply, since the notion that actors are sore losers presupposes that the opposition's misgivings must be at least to some extent unjustified. However, as we have seen, other mechanisms can still trigger conflicts. In case of electoral noncompetitiveness, there may exist groups that have been excluded from the electoral competition at the outset and thus excluded from any meaningful potential access to political power. Such exclusion is likely to be especially entrenched if 
supported by "sticky" categorical markers, such as membership in ethnic groups. Based on this reasoning, we postulate that noncompetitive elections are more likely to trigger ethnic, rather than nonethnic, violence:

\section{Hypothesis $2 b$ (H2b): Noncompetitive elections increase the likelihood} of ethnic civil wars more than nonethnic civil wars.

Buhaug (2006) furthermore argues that specific incompatibilities of the actors delineate important forms of variation in civil war, and he presents evidence suggesting that territorial and governmental conflict are generated by fundamentally different processes. Hence, it is necessary to proceed beyond distinguishing only ethnic and nonethnic conflicts and also to consider the specific incompatibility over which violence is used. Conflicts that hinge on territorial incompatibilities, such as civil wars involving movements that seek autonomy or independence for particular regions, are usually associated with distinct ethnic groups. However, governmental conflicts involve direct challenges to the center of the state and are much less likely to emanate from movements based on a specific ethnic affiliation (indeed, many military coups may be seen as efforts by factions already in the central government or army to seize greater control). In the following, we consider mechanisms driving each type of civil war separately, starting with the mechanisms driving governmental civil wars.

We start by considering the electoral mechanisms that may trigger territorial civil wars. Marginalized ethnic groups that are small relative to the country's total population are much more likely to pursue territorial aims, such as secession or various degrees of autonomy, rather than attempting to seize central state power.

For territorial civil wars, we thus expect that the election effect relates to conflicts over the very boundaries of the demos rather than to the exact power relations within it (Dahl, 1989). By inviting citizens to participate in national politics, elections imply a certain level of commitment to the polity as a whole, but disagreements over who is included within the popular unit corresponding to the democratic system may trigger conflict (Rustow, 1970). In particular, leaders of competing ethnic groups can use electoral campaigns to drum up support for secessionist or autonomist platforms that challenge the sovereignty of the state. In such cases, political violence may become an attractive alternative to democratic participation.

Given that the very definition of the polity is at stake, the demos effect should operate independent of whether elections are truly competitive or not. The resistance of ethno-nationalist groups that are unhappy with current state borders is unlikely to be mollified by competitive elections. This is so because elections tend to confirm, and render more visible, the current power structure, including structures of dominance and imposed "alien" rule. 
In brief, this reasoning yields the following hypothesis:

Hypothesis 3 (H3): The likelihood of territorial ethnic civil war increases after both competitive and noncompetitive elections.

Having briefly discussed our theoretical expectations as regards territorial conflict, we now turn to civil wars featuring direct challenges to the government. Governmental conflicts are also likely to result from elections regardless of the degree of competitiveness in electoral politics. Yet for this type of conflicts, we differentiate between two main mechanisms that are associated with either type of elections.

Previous research (see, e.g., Cederman, Wimmer, \& Min, 2010) indicates that larger ethnic groups are generally more likely to become involved in civil wars with the state. Here we assume that the size effect is especially important for governmental conflicts because only the largest groups are capable of or willing to claim central power (see Table A3 in the appendix (see online) for a list of the cases where governmental conflicts follow elections).

In addition, we postulate that direct challenges to governmental power are more likely following elections because electoral events increase the level of political competition and lead to large-scale mobilization, especially where large groups are dissatisfied with the outcome of the election. Horowitz (1985, p. 331) describes how such "polarizing elections" are likely to provoke ethnic coups. Thus, the sore-loser effect, whether driven by honest or dishonest behavior of the incumbent, should be larger wherever a larger proportion of the population feels excluded from power. Events in the Ivory Coast illustrate this mechanism again quite clearly. The two groups facing each other in the dispute over the election result were both large, and the violence took place over the issue of control of the government.

Unfortunately, our election coding does not extend to electoral outcomes linked to groups. However, we can use the demographic size of the ethnic group in question as a proxy for the sore-loser effect.

Hypothesis 4 (H4): After competitive elections, large ethnic groups are more likely to fight the government than small ethnic groups.

\section{Country-Level Analysis}

An initial test of our hypotheses at the country level gives us the opportunity to check whether the families of mechanisms reviewed above appear to point in the right direction before proceeding to disaggregate by ethnic group and 
conflict incompatibility. In this section, we propose a simple model considering the effects of elections on the risk that a country will experience conflict. The information on elections comes from data collected by Golder (2004) and Hyde and Marinov (2010). ${ }^{7}$ We consider only elections to national office (presidency or seat in parliament or constituent assembly) and the time period from 1960 to 2000 since Hyde and Marinov (2010) do not cover elections prior to 1960 and Golder's (2004) data do not extend beyond 2000. To identify the subset of elections that are competitive, we follow Hyde and Marinov's (2010, p. 8) classification, which, for an election to be competitive, requires that the following three questions be answered in the affirmative: "(1) Was opposition allowed? (2) Was more than one party legal? (3) Was there a choice of candidates on the ballot?" ${ }^{\prime 8}$ Since all elections extracted from Golder's (2004) data sets occurred in developed democracies, we consider them competitive, except the elections in Portugal before 1974. As the criteria used by Hyde and Marinov (2010) suggest, competitive elections are not necessarily identical to "free and fair elections." More specifically, whether elections are competitive could be determined ex ante, whereas assessing whether elections were "free and fair" required ex post information and thus is much more difficult to do in an objective fashion (e.g., Bratton, 1998). ${ }^{9}$

Our data on civil war onset are based on the Uppsala-PRIO Armed Conflict Data (see Gleditsch, Wallensteen, Eriksson, Sollenberg, \& Strand, 2002; Harbom \& Wallensteen, 2009). To establish the involvement of specific ethnic groups in conflict, we draw on a new data project called ACD2EPR that information from the Non-State Actor (NSA) data on rebel groups in the Armed Conflict Data (Cunningham et al., 2009) and the Ethnic Power Relations (EPR) data set on politically relevant ethnic groups (Cederman, Wimmer, \& Min, 2010). We code conflicts as involving ethnic groups if there is a clear link to rebel organizations, in terms of both their fighters' ethnicity and their claims to operate on behalf of the group in question. ${ }^{10}$ We estimate a multinomial logit model, ${ }^{11}$ where we distinguish between the risk of ethnic and nonethnic conflicts, contrasting both to the reference category of no conflict. Tables A2 and A3 in the appendix list the relevant conflict cases, divided into ethnic and nonethnic wars. We also include a number of control variables commonly believed to be associated with civil war that may also plausibly be linked to democratization and elections, including the GDP per capita of the country in question, its population size, and the proportion of the population that is excluded from executive power according to the EPR data set (for a more detailed discussion of the control variables, see Cederman, Hug, et al., 2010; Wimmer, Cederman, \& Min, 2009). ${ }^{12}$ Observations with ongoing conflicts are coded as missing, and we address the potential time dependence of 
conflict by using the nonparametric approach suggested by Beck, Katz, and Tucker (1998), including time since previous conflict (or independence) as well as three cubic splines on the right-hand side of the model. Table 1 reports the empirical results, with robust standard errors clustered by country to take into account variation across countries not reflected in the covariates.

In Model 1.1 in Table 1, we find a positive coefficient for elections on ethnic civil war, indicating that elections make civil war more likely in the subsequent year. However, the coefficient is at best marginally statistically significant and barely crosses the 0.10 level. ${ }^{13}$ We find a small negative coefficient for elections on nonethnic civil wars, which is far from statistical significance at conventional levels. ${ }^{14}$ In substantive terms, the probability of an outbreak of an ethnic civil war in a given year for an observation with all other variables held at the mean values increases from 0.004 to 0.007 in the year following an election. ${ }^{15}$ The risk of a nonethnic civil war decreases from a baseline probability of 0.014 to 0.012 in the year following an election. Hence, at the country level, the evidence for a positive effect of elections on civil war is not very consistent, and there is little evidence for any effect at all on nonethnic civil wars. In this sense, the results seem quite in line with the general findings regarding the general effect of democratization on civil war, where some country-level studies suggest a positive effect but the findings seem fragile and not very robust across alternative specifications.

Among the ethnic conflict outbreaks linked to elections in Africa for the period studied by Lindberg (2009), in two out of three cases the losers did not at first accept the election result. More specifically, competitive elections in Niger in 1995 and in Chad 1996 were both followed by ethnic conflict. In the case of Congo in 1992, the elections were also followed by an ethnic conflict, but according to Lindberg's (2009) data the losers of the election actually accepted the election result.

Before distinguishing between types of elections, we briefly comment on the results for the control variables, which are largely consistent with previous research. The share of the population composed by ethnic groups excluded from executive power has a particularly large estimated positive effect on the onset of ethnic conflict, but the coefficient is smaller and less significant for nonethnic conflicts. Per capita income has a consistently negative effect on nonethnic civil wars, in agreement with Fearon and Laitin (2003). The negative effect is somewhat less consistent for ethnic civil wars, although the coefficient suggests a larger effect on the log odds of conflict (see Buhaug et al., 2008). Population size has a positive effect on ethnic civil wars but essentially no statistically significant effect on nonethnic civil wars. In general, our results support Buhaug's (2006) claim that many features 


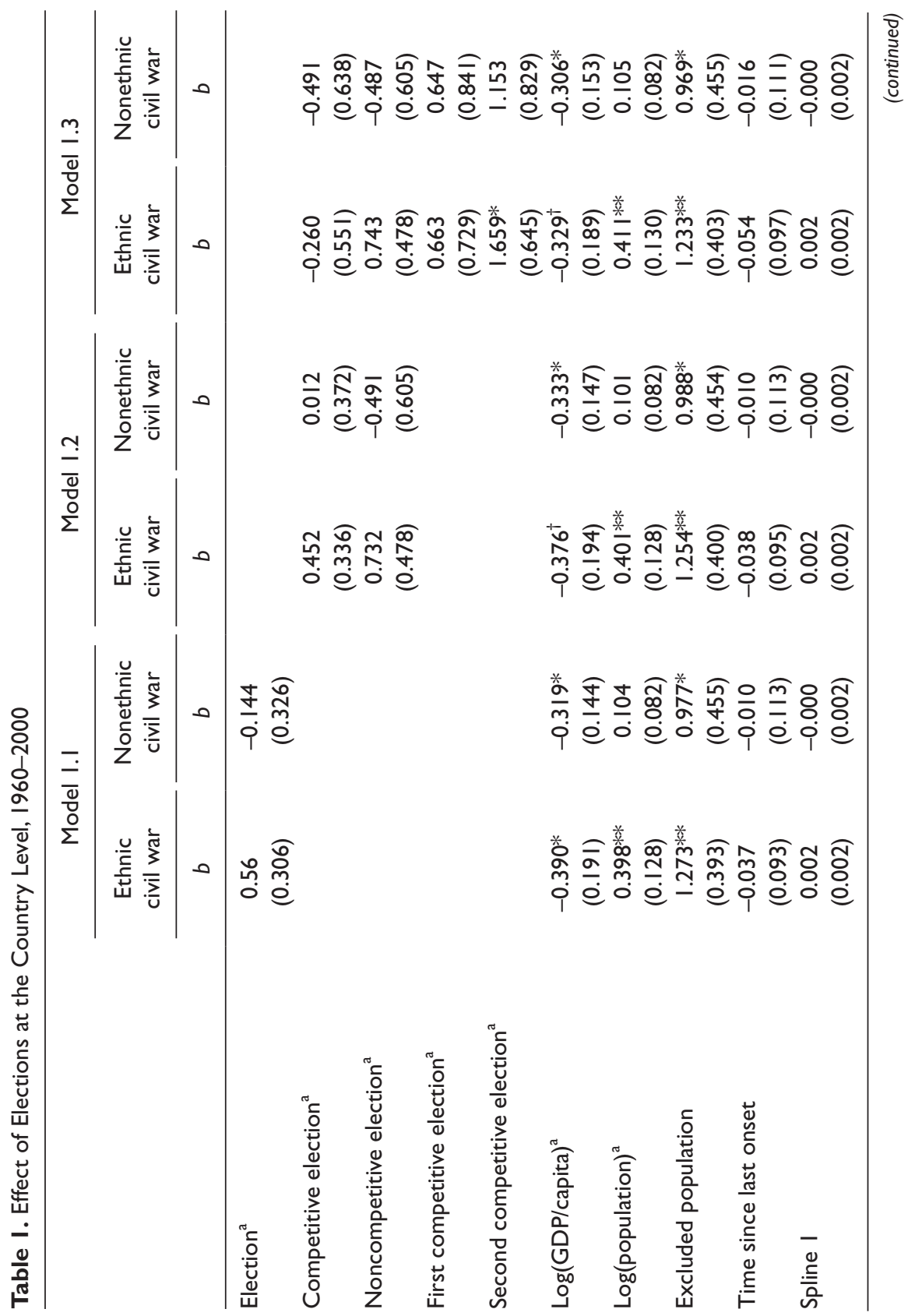




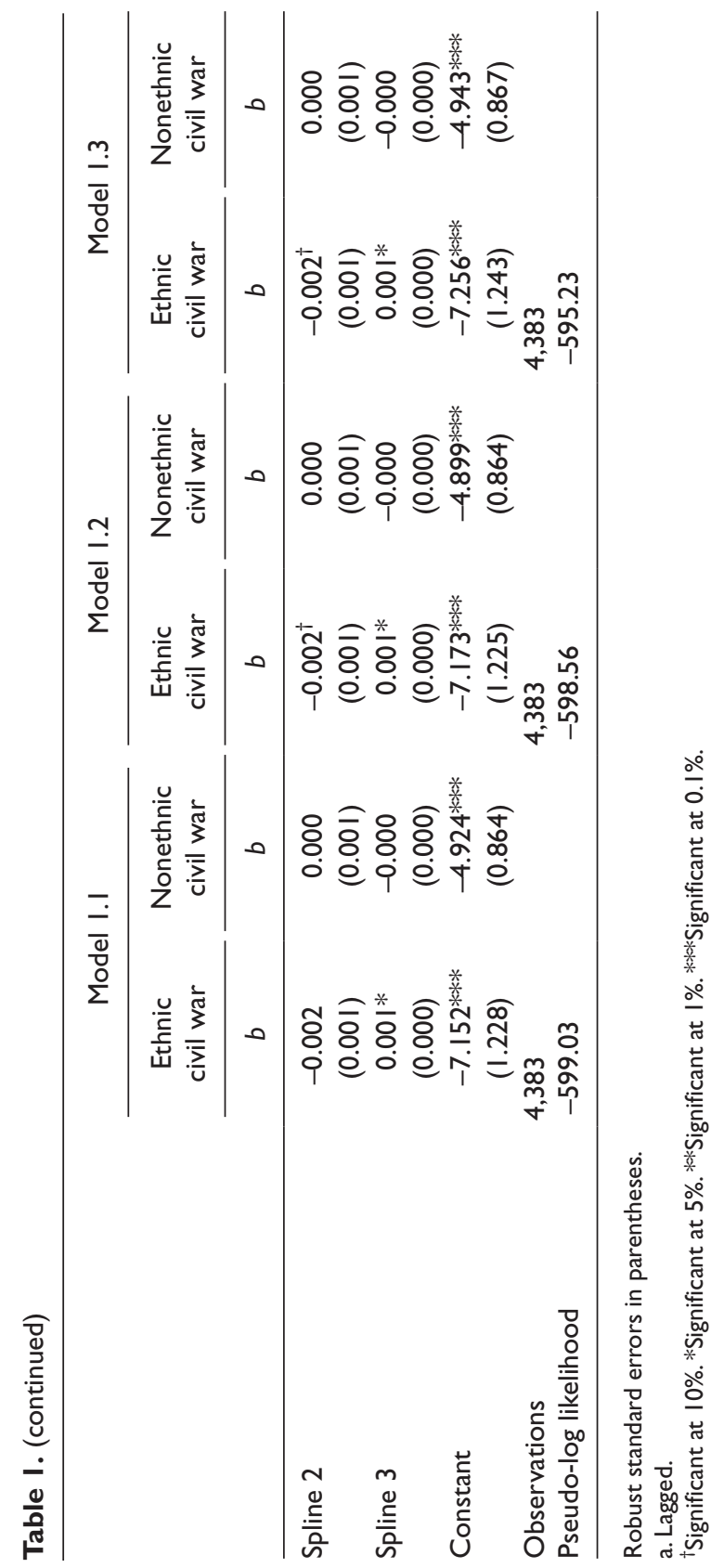


have different effects on ethnic and nonethnic civil wars and that general results on civil war will reflect a mixture of the different and sometimes competing influences of covariates on the risk of different types of conflicts (see, e.g., Hegre \& Sambanis's, 2006, sensitivity analysis).

Our second set of hypotheses suggests that the effect of elections on civil war will be contingent on their character, namely, whether they are competitive or not as well as potentially their timing. Model 1.2 reports the results of a test distinguishing between competitive and noncompetitive elections. We find at best marginal support in these results for $\mathrm{H} 2 \mathrm{a}$ - suggesting that competitive elections increase the likelihood of both ethnic and nonethnic civil war-since the effects of competitive elections on civil war are positive for ethnic conflict only and negative for nonethnic civil wars. However, although the coefficients for competitive elections on ethnic civil war in Model 1.2 are of a magnitude comparable to the general effects of elections in Model 1.1, the coefficient just barely misses the .1 level in a one-tailed test. ${ }^{16} \mathrm{H} 2 \mathrm{~b}-$ arguing that noncompetitive elections increase the likelihood of ethnic civil wars more than nonethnic civil wars-also finds merely marginal support in the results of Model 1.2 since the coefficient for noncompetitive elections on the likelihood of ethnic civil war onset is positive (and close to significance at the .1 level in a two-tailed test) but negative for nonethnic civil wars. ${ }^{17}$ Our results thus suggest that sore-loser mechanisms could play a role in both competitive and noncompetitive elections. However, the relatively large standard errors imply that there is a lot variation across elections at the country level, and the general evidence for any positive effects of elections on civil conflict is at best weak.

Drawing on arguments by Bratton (1998) and Strand (2007), we distinguish first and second competitive elections from competitive elections in general (see Model 1.3 in Table 1). We consider as first competitive elections those polls that were preceded by a period without elections for at least 5 years or noncompetitive elections. The results for Model 1.3 reveal that any effect of competitive elections on ethnic civil conflict seems to stem exclusively from the initial competitive elections, as the coefficient from competitive elections in general has a negative sign close to 0 , reflecting that there is no tendency that competitive elections in general promote conflict. However, we have much larger positive coefficients for first and second competitive elections, and the positive effect is particularly strong for the second competitive elections on ethnic civil wars. Substantively, the results imply an increase in the risk of an ethnic conflict onset from a baseline of 0.004 at the mean to 0.016 in the year following an election. ${ }^{18}$ For nonethnic wars, the effect of second and first competitive elections is smaller. These results contrast with 
those of Collier et al. (2008), who find a higher rate of conflict relapse in the year after the first election, which then decreases for the following election. However, it should be recalled that they consider only the effects of elections in postconflict states, and hence consider a much more restricted sample than our analyses, which include all states with new competitive elections. ${ }^{19}$

Although these country-level findings provide some support for the hypotheses on how elections may increase the risk of outbreaks civil wars, we cannot evaluate to what extent these results confirm that the groups actually engage in conflict in accordance with the postulated mechanisms without disaggregating to the level of individual ethnic groups. To do this, we now turn to our analyses of conflict at the group level.

\section{Group-Level Analysis}

Building directly on the EPR data set, we use as our units of analysis the individual politically relevant ethnic groups around the world from 1960 through 2000 (Cederman, Wimmer, et al., 2010). Constrained by the availability of electoral data, this group-level data set covers all politically relevant ethnic groups, irrespective of their size and access to national executive power. Apart from increasing the amount of information about individual conflicts and the involvement of specific ethnic groups, a group-level conflict analysis also has the advantage of not discarding information about whether other groups engage in conflict in the presence of conflicts by one group, as country-level analysis by construction disregards all the instances of peaceful groups in a country if a single ethnic group is involved in conflict. Consequently, although in our country-level analysis we have only 81 ethnic civil war onsets (and 86 nonethnic civil war onsets), we have 127 individual conflict onsets by ethnic groups in the group-level analysis. ${ }^{20}$ This allows us also to distinguish in a meaningful way among different types of conflicts that specific ethnic groups may engage in.

Before proceeding to evaluate our group-specific hypotheses, we first consider whether the main country-level findings reported in Table 1 can be replicated at the group level, or how the turn to disaggregated data may affect our previous conclusion on the general election effect (H1). Model 2.1 in Table 2 includes a number of group-level and country-level features likely to influence ethnic groups' involvement in ethnic conflict. This list features a dummy variable that indicates whether the ethnic group was excluded from executive power as well as a variable measuring the group's share of the country's population (both variables drawing on the EPR data set). We also retain the main control variables from the country-level analysis that measure 
the relevant state's GDP per capita and total population. Finally, the models also feature a control variable that counts the number of prior conflicts that the group has experienced since 1946 or independence of the country in question. $^{21}$

As can be seen, we again have a positive coefficient for elections (Model 2.1), but since the coefficient is barely larger than its standard error, we again certainly do not find very strong evidence in favor of a general positive effect of elections on conflict. Before turning to the differences between competitive and other elections and their sequence, we first briefly comment on the results for the other terms in the model. In line with previous scholarship, we find that excluded groups are much more likely to experience conflict, and conflict is much more likely in instances where a group has previously been involved in a conflict (see Cederman, Wimmer, \& Min, 2010). Average country income has a negative coefficient on the risk of conflict. Finally, total country size has a positive estimated coefficient on the risk of conflict, but this effect fails to reach statistical significance.

Model 2.2 examines whether the relatively weak findings for elections in general may reflect mixed effects of competitive and noncompetitive elections. This model provides at least in part some support for this view, as the positive coefficient indicates that ethnic groups become more likely to engage in conflict following competitive elections (and the coefficient is close to significance at the .10 level), whereas the estimated effect of noncompetitive elections is very close to 0 . Together these findings strengthen our confidence in both $\mathrm{H} 2 \mathrm{a}$ and $\mathrm{H} 2 \mathrm{~b}$ and confirm that the election effects for ethnic civil wars seem clearer when we look at all groups that might fight rather than aggregate ethnic conflict at the country level. Model 2.3 considers the differences among first, second, and other competitive elections. Again, we find that the increase in risk seems to follow from the first and in particular second elections, and that there are no effects of competitive elections in general. ${ }^{22}$ However, neither of the terms for first or second competitive elections is clearly significant by conventional standards.

We now proceed to assess our hypotheses on the specific risks of territorial and governmental civil conflict. Table 3 introduces three multinomial logit regressions. The simplest specifications, Models 3.1 and 3.2, examine the previous model specifications separating between territorial and governmental conflicts. We now find much stronger evidence for significant impacts of elections on conflicts, and we note that the signs of the coefficient for elections differ for territorial conflicts (positive) and governmental conflicts (negative). Hence, the overall coefficient for ethnic conflicts in Table 2 will reflect an average across the two types of conflicts, where the two opposing 
Table 2. Group-Level Onset of Ethnic Conflict, I 960-2000

\begin{tabular}{|c|c|c|c|}
\hline & Model 2.I & Model 2.2 & Model 2.3 \\
\hline & $\begin{array}{l}\text { Ethnic } \\
\text { civil war }\end{array}$ & $\begin{array}{l}\text { Ethnic } \\
\text { civil war }\end{array}$ & $\begin{array}{l}\text { Ethnic } \\
\text { civil war }\end{array}$ \\
\hline & $b$ & $b$ & $b$ \\
\hline Election $^{\mathrm{a}}$ & $\begin{array}{c}0.279 \\
(0.270)\end{array}$ & & \\
\hline Competitive election $^{\mathrm{a}}$ & & $\begin{array}{c}0.413 \\
(0.27 I)\end{array}$ & $\begin{array}{c}0.118 \\
(0.409)\end{array}$ \\
\hline Noncompetitive election $^{a}$ & & $\begin{array}{c}0.041 \\
(0.427)\end{array}$ & $\begin{array}{c}0.039 \\
(0.426)\end{array}$ \\
\hline First competitive election ${ }^{a}$ & & & $\begin{array}{c}0.409 \\
(0.504)\end{array}$ \\
\hline Second competitive election ${ }^{a}$ & & & $\begin{array}{c}0.541 \\
(0.497)\end{array}$ \\
\hline Group excluded & $\begin{array}{l}\mathrm{I} .32 \mathrm{I} * * * \\
(0.26 \mathrm{I})\end{array}$ & $\begin{array}{l}\text { I.334*** } \\
(0.26 I)\end{array}$ & $\begin{array}{l}\text { I.334*** } \\
(0.262)\end{array}$ \\
\hline log(relative group size) & $\begin{array}{l}0.330^{* * *} \\
(0.08 \mathrm{I})\end{array}$ & $\begin{array}{l}0.328^{* * *} \\
(0.081)\end{array}$ & $\begin{array}{l}0.330^{* * *} \\
(0.082)\end{array}$ \\
\hline $\log (G D P / c a p i t a)^{a}$ & $\begin{array}{c}-0.464^{* *} \\
(0.147)\end{array}$ & $\begin{array}{c}-0.47 I^{* *} \\
(0.148)\end{array}$ & $\begin{array}{c}-0.454^{* *} \\
(0.149)\end{array}$ \\
\hline $\log (\text { country population })^{a}$ & $\begin{array}{c}0.122 \\
(0.1 \mid 2)\end{array}$ & $\begin{array}{c}0.121 \\
(0.11 I)\end{array}$ & $\begin{array}{c}0.124 \\
(0.112)\end{array}$ \\
\hline Prior conflict & $\begin{array}{l}0.858^{* * *} \\
(0.165)\end{array}$ & $\begin{array}{l}0.862^{* * * *} \\
(0.166)\end{array}$ & $\begin{array}{l}0.86 \mid * * * \\
(0.166)\end{array}$ \\
\hline Peace years & $\begin{array}{c}-0.076 \\
(0.061)\end{array}$ & $\begin{array}{c}-0.076 \\
(0.060)\end{array}$ & $\begin{array}{c}-0.078 \\
(0.060)\end{array}$ \\
\hline Spline I & $\begin{array}{c}0.000 \\
(0.000)\end{array}$ & $\begin{array}{c}0.000 \\
(0.000)\end{array}$ & $\begin{array}{c}0.000 \\
(0.000)\end{array}$ \\
\hline Spline2 & $\begin{array}{l}-0.001 \\
(0.000)\end{array}$ & $\begin{array}{c}-0.001 \\
(0.000)\end{array}$ & $\begin{array}{c}-0.001 \\
(0.000)\end{array}$ \\
\hline Spline3 & $\begin{array}{l}0.001^{* *} \\
(0.000)\end{array}$ & $\begin{array}{l}0.00 I^{* *} \\
(0.000)\end{array}$ & $\begin{array}{l}0.00 I^{* *} \\
(0.000)\end{array}$ \\
\hline Constant & $\begin{array}{c}-2.099 \\
(1.244)\end{array}$ & $\begin{array}{c}-2.051 \\
(1.237)\end{array}$ & $\begin{array}{l}-2.211 \\
(1.265)\end{array}$ \\
\hline $\begin{array}{l}\text { Observations } \\
\text { Log pseudolikelihood }\end{array}$ & $\begin{array}{r}17,920 \\
-683.685\end{array}$ & $\begin{array}{r}17,920 \\
-683.21 \mid\end{array}$ & $\begin{array}{r}17,920 \\
-682.682\end{array}$ \\
\hline
\end{tabular}

Robust standard errors in parentheses

$* *$ Significant at $1 \%$.*** Significant at $0.1 \%$.

a. Lagged. 


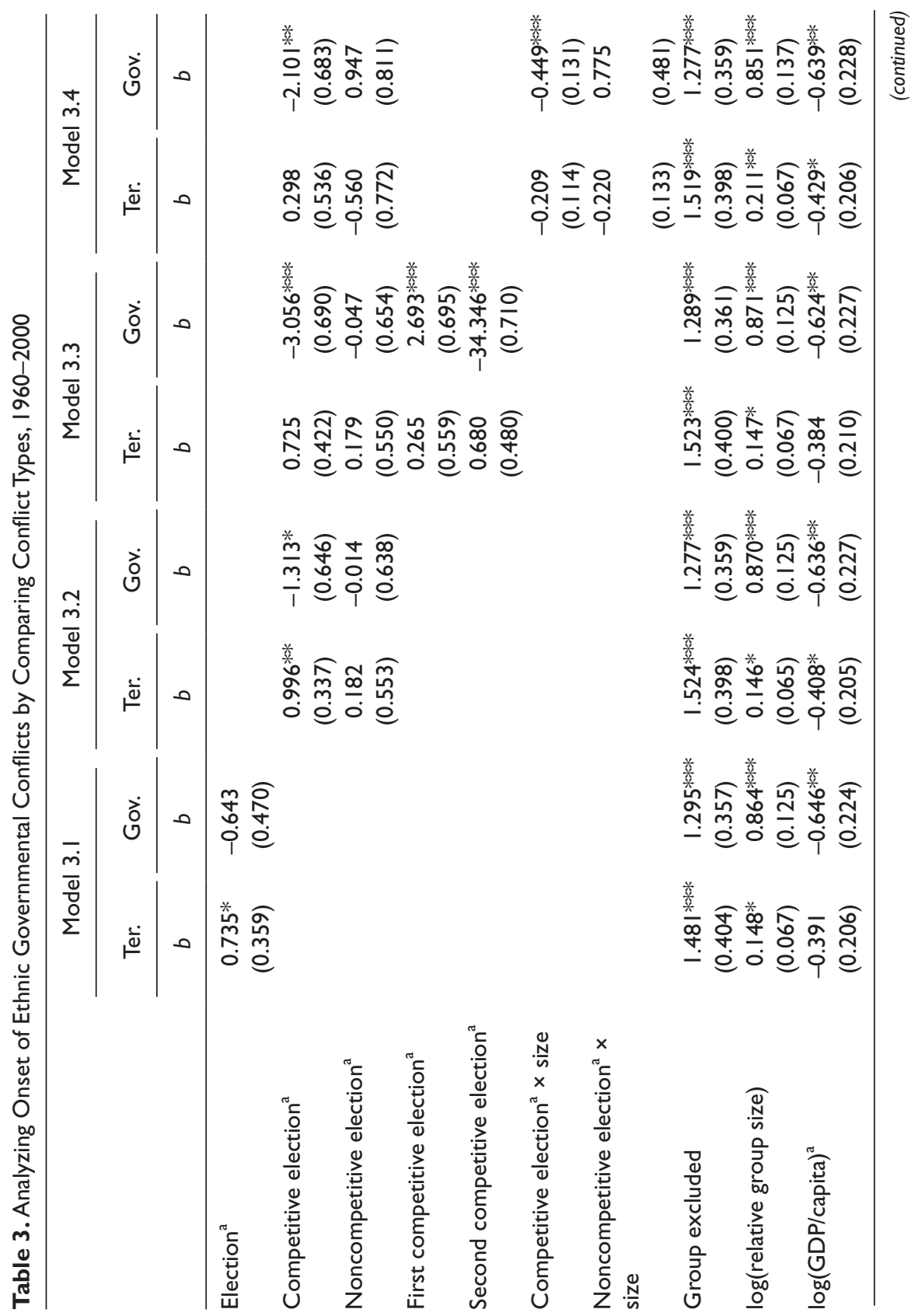




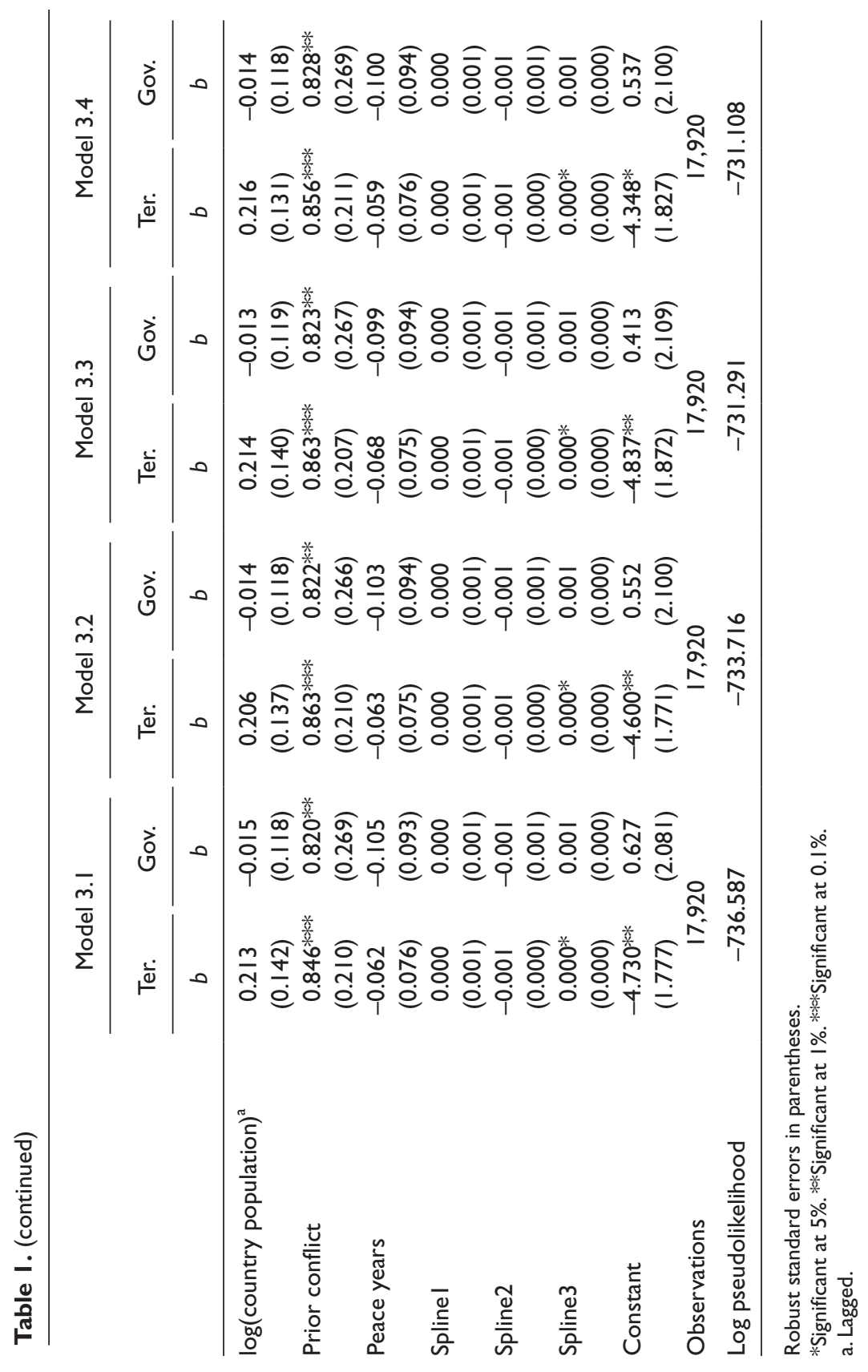


effects wash each other out. More specifically, the results in Model 3.1 indicate that territorial conflicts are indeed more likely after elections, as suggested by H3. ${ }^{23}$ Model 3.2 shows that this election effect for territorial conflict is largely the result of competitive elections. ${ }^{24}$ By contrast, elections actually have a negative effect on governmental conflict onsets in Model 3.1, which is upheld for competitive elections in Model 3.2, where the effect becomes clearly statistically significant and has a larger impact on the log odds than the coefficient for territorial conflict. The results for the control variables are relatively similar across the two set of conflict outcomes and also similar to the results in Table 2.

When returning to our distinction between first and second competitive elections in Model 3.3, we find that the second competitive election again has a large positive (although statistically not significant) effect on the probability of a territorial civil conflict, whereas the first competitive elections, although the coefficient is positive, have a much smaller effect. ${ }^{25}$ By contrast, competitive elections in general strongly reduce the likelihood of governmental conflict, whereas the coefficient for first competitive elections suggests a positive effect, implying that the first competitive election is almost as risk prone as a nonelection year. Finally, Model 3.3 also reports a strong negative effect of second competitive election for governmental conflicts, but strictly speaking this coefficient is unidentified since there are no governmental conflicts after second competitive elections in our sample, thus the estimation of this effect is subject to a complete separation problem (see Zorn, 2005).

In Model 3.4 we investigate the size dependence of the electoral effects on civil wars (see H4). Model 3.4 introduces an interaction term between group size and both competitive and noncompetitive elections, which allows us to examine how the election effects differ from groups of different sizes.

The findings demonstrate a powerful and highly significant size-dependent effect of elections. ${ }^{26}$ We depict the substantive effects in Figure 1. For territorial conflicts, we find that in the absence of elections, larger groups are marginally more likely to engage in conflicts. However, this effect is eliminated or reversed in the aftermath of noncompetitive and competitive elections, respectively. This provides evidence against our $\mathrm{H} 4$.

Governmental conflicts in the absence of elections are more likely for larger groups. As Model 3.4 shows, competitive elections reduce the likelihood of such conflicts, and the former also reduce the group size effect. As Figure 1 illustrates, especially for large groups, the joint effect of competitive elections leads to a slightly larger conflict risk. We find, however, a similar though smaller size effect even in the absence of elections. Similarly the 

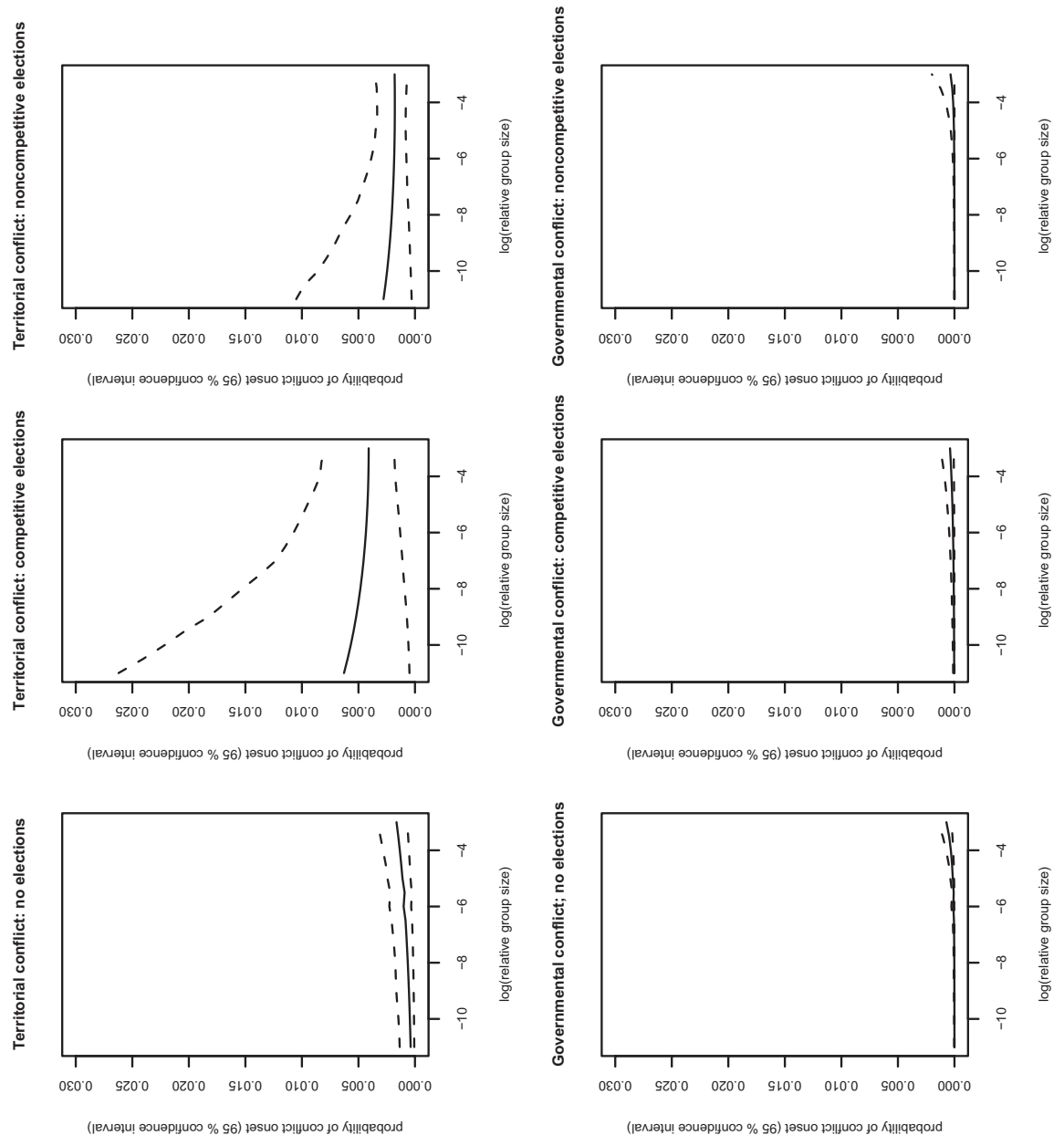
aftermath of noncompetitive elections is associated with a considerable increase in the predicted probability of governmental conflicts for especially large groups.

These results are important from at least two points of view. First, at the substantive level we find that elections have different effects for larger and smaller groups, and that the effects depend on type of the election (i.e., whether competitive and sequence order). Smaller groups are more likely to engage in territorial conflicts after elections. These groups are on the other hand almost never involved in governmental conflicts, whether or not elections are held. The same cannot be said for large groups. The latter are much more likely to engage in governmental conflict, and they do so especially after noncompetitive elections.

Second, our results also highlight how disaggregating our analysis enables us to detect what causal mechanisms may be operating in democratization processes in general, and in the aftermath in elections more specifically. Without the disaggregated analysis, the results of the effect of elections would reflect different tendencies that can cancel each other in the aggregate.

\section{Conclusion}

In this article we have explored the effect of elections on internal conflict or civil war from the perspective of ethnic groups, while taking into account the nature and specific sequence of elections. Although we find that the general relationship between a risk of conflict and elections is much weaker than often suggested by many observers, we do find that there are specific circumstances where the risks of conflict in the aftermath of elections can be more substantial. Our results demonstrate that elections appear to primarily generate ethnic civil wars, and our group-level analysis suggests that the electoral influence on conflict can manifest itself in different ways, depending on the type of ethnic conflict and type elections. We have shown that the problem of postelection violence primarily arises in the first two competitive elections, and that elections per se are not particularly dangerous. Moreover, the conflict-inducing election effect is mediated through the relative size of ethnic groups. Furthermore, we find large differences between the risk of territorial and governmental conflicts, suggesting that conflicts over the territorial limits of a polity and the specific composition of the government in the wake of elections are driven by very different processes. Our study sheds light on the problem of postelectoral violence and the risks of conflict emanating from democratization and greater political accountability. Because democratization is a notoriously difficult concept to measure, our focus on 
elections offers a useful complement to previous democratization and conflict research. By disaggregating such effects, in terms of both the level of analysis and the type of conflict, we are able to come closer to the causal mechanisms that may underlie the outbreak of conflict in the wake of political reform and democratization. At the same time, by focusing more directly on the ethnic groups involved in conflict, we can also offer insights into what power configurations are most at risk of postelection violence. As groups excluded from power appear to play a major role in these instances, this offers a policy-relevant insight that in the absence of an open political process, elections are especially conflict prone (also see Höglund et al., 2009).

Yet our current analysis remains in many ways preliminary, and there is considerable scope for extensions and improvement in terms of both theory and data. More direct tests of the main theoretical explanations would be highly desirable. In particular, an evaluation of the sore-loser logic would benefit from data on electoral outcomes linked to the groups in our sample. Moreover, our group-level analysis leaves out an important layer of political actors, such as political parties and rebel organizations, which usually are the directly responsible and active agents in the outbreak of conflicts. Information about such organizations can be very helpful in further evaluating competing explanations of the influence of ethnic politics on civil war violence (see Birnir, 2007). The current research design, based on yearly observations, is relatively crude as regards the precise sequence of elections and violence. Event history analysis models, with more precise information about dates of elections and conflict onset, could improve the precision of causal inference, although the relative timing may be difficult to tease out without better data, especially since low-level conflict makes it difficult to pin down the specific violent events or any exact starting point for a civil war.

Our results suggest a more nuanced view of the perils and promises of democratization and elections than what has so far been offered in previous research. Whether, and to what extent, elections entail a risk of conflict depends on the character of ethnic groups in a country and their political status. Although there is a genuine tendency for competitive elections to precede conflict outbreaks, these are primarily limited to the first two elections. Integrating such knowledge on how elections may introduce incentives for ethnic violence with findings from the power sharing literature may further help make progress on devising practical measures to counteract such incentives, including possible guarantees to prevent postelection exclusion and discrimination or proactive security measures, potentially including external actors under the auspices of international organizations. 


\section{Acknowledgments}

We gratefully acknowledge helpful comments on an earlier version of this article by Jóhanna Birnir, Cees van der Eijk, Peter Sandholt Jensen, and participants at the CSCW Workshop on "Institutional Constraints to Violence," University of Nottingham, UK, April 16-17, 2009, at the Joint CSCW WG3/GROW-Net workshop, PRIO, June 11-12, 2009, and at the Democratization and Civil War workshop, Zürich, October 2, 2009. Thanks are also due to Susan Hyde, Matt Golder, and Nikolay Marinov for making their election data available to us and answering patiently our numerous queries. We acknowledge the able research assistance by Philippe Hunziker, Lutz Krebs, and Julian Wucherpfennig.

\section{Declaration of Conflicting Interests}

The author(s) declared no potential conflicts of interest with respect to the research, authorship, and/or publication of this article.

\section{Funding}

The author(s) disclosed receipt of the following financial support for the research, authorship, and/or publication of this article: Gleditsch was supported by the Research Council of Norway (180441/V10) and the U.K. Economic and Social Research Council (RES-062-23-0259). Cederman and Hug acknowledge the financial support of the Swiss National Science Foundation through the NCCR Democracy in the 21st Century and Grant 105511-116795.

\section{Notes}

1. The breakup of the former Yugoslavia clearly includes elements of both intraand interstate conflict. Mansfield and Snyder (1995) also highlighted Rwanda as a supportive case for their theory, yet it is difficult to see how this can characterized as an interstate conflict.

2. Hegre, Ellingsen, Gates, and Gleditsch (2001) also discuss the implications of the effects of democratization on civil war, but their approach does not explicitly consider democratization or changes in degree of democracy. In addition, Treier and Jackman (2008) and Vreeland (2008) suggest that the Polity IV indicators can be problematic for testing the effects of political regimes on conflict and argue that the estimated effects of changes in level of democracy (as reflected in the Polity scale) on conflict are reduced when these issues are addressed (although also see Gleditsch, Hegre, \& Strand, 2009; Marshall \& Cole, 2008).

3. Obviously, elections are not limited to democracies but can also occur under authoritarian rule (see, e.g., Hyde \& Marinov, 2010; Levitsky \& Way, 2002; Lust-Okar, 2006).

4. This idea of ethnic outbidding can be seen as predicated on Deutsch's (1953, p. 104) idea of mobilization and assimilation as a source of national conflict. 
However, Deutsch refers primarily to social rather than to political mobilization. Similarly, assimilation is not related to access to power since it again refers to social communication in the context of the dominant culture.

5. See also the examples discussed in Hoddie and Hartzell (2005).

6. Below, based in part on Collier (2009) and Höglund, Jarstad, and Söderberg Kovacs's (2009) arguments, we will also assess the effect of the first and second competitive elections. We expect that the effects postulated in our hypotheses for competitive elections will be strongest in these cases.

7. Given the different coverage and emphasis of these two data sets, we use as a starting point the Hyde and Marinov (2010) data and complete them with the information from Golder (2004) for the countries not covered in the first source. These countries are Austria, Belgium, Canada, Denmark, Finland, France, Ireland, Italy, Japan, the Netherlands, New Zealand, Norway, Portugal, Sweden, Switzerland, the United Kingdom, the United States of America, and West Germany. We code as first competitive election the following elections: (a) first competitive election after independence, (b) all competitive elections preceded by a noncompetitive election, and (c) all competitive elections preceded by 5 years without elections. The second competitive election is the next election after the first competitive election, provided it is competitive.

8. In an earlier version we followed Birnir (2007) and relied on International Institute for Democracy and Electoral Assistance (IDEA's) coding using the Quality of Government data set (Teorell, Charron, Samanni, Holmberg, \& Rothstein, 2009). Careful checking, however, revealed that the coverage of the IDEA data seemed incomplete, and they cannot be assumed to cover all elections.

9. Obviously, the effect of elections might also differ according to other criteria, most notably depending on whether they occur in postconflict periods. Such other elements are, however, beyond the scope of this article and would need a more detailed theoretical treatment. We have checked the robustness of our empirical results, however, by assessing whether the effects of elections are different in postconflict periods and whether the distinction between presidential and legislative elections might affect our results. As the results reported in our online appendix (available at http://cps.sagepub.com) suggest, only minor changes appear for these different types of elections; hence, we refrain from discussing them here in the main text and will explore them in future work.

10. We use this conflict coding with a threshold of 25 battle deaths, while removing three instances where the United States is coded as being involved in an internationalized civil war, since these conflicts either did not take place on its core territory or did not involve indigenous groups. Years with ongoing conflicts were dropped from the analysis. 
11. We also estimated all the multinomial logit models reported as multinomial probit models, which are sometimes seen as preferable since they do not rely on the assumption of the independence of irrelevant alternatives. The choice of estimator here does not affect any of the substantive interpretations, and we report only the multinomial logit estimates.

12. Elections, obviously, do not occur randomly, and thus our empirical analysis might be affected by endogeneity bias. For this reason we include a series of control variables that are known to be associated with conflict onset and that might also be related to the timing of elections (see Flores \& Nooruddin, 2010, for a discussion of these issues). We believe, however, that election timing is a concern especially in postconflict situations (see Brancati \& Snyder, 2010). As our robustness checks suggest, however, our main results do not differ in postconflict periods.

13. Given the yearly data, this coefficient is likely to be biased toward zero since in some cases an election and a conflict onset happen in the same year in the sequence expected according to our hypotheses. Our lagged election variable will, however, not pick up such civil war onsets.

14. All other variables were held constant at their mean values except the variables taking into account time dependence. All these were set to the values corresponding to the closest integer of the mean number of peace years, namely 20 . The standard errors for the two probabilities and the two changes in probabilities are $0.001,0.003,0.002$, and 0.004 respectively.

15. These, as all subsequent predicted probabilities, were calculated with the help of Clarify (Tomz, Wittenberg, \& King, 2003).

16. In terms of substantive effects, for a median observation profile, competitive elections increase the probability of an ethnic war by $0.002(S E=0.002)$ from $0.004(S E=0.001)$ in the absence of elections, while increasing the probability of a nonethnic war by $0.001(S E=0.005)$ from $0.014(S E=0.003)$ in the absence of elections.

17. The substantive effects are as follows: Noncompetitive elections increase the probability of an ethnic war by $0.005(S E=0.004)$ from $0.004(S E=0.001)$ while changing the probability of a nonethnic war by $-0.004(S E=0.007)$ from 0.014 $(S E=0.003)$

18. The standard errors for the probability and change in probability are 0.001 and 0.008 , respectively.

19. In robustness checks reported in our online appendix, we find that, however, that the results reported here remain robust even when we consider postconflict elections separately.

20. Of these, 78 are territorial conflicts, whereas the remaining 49 are governmental conflicts. 
21. As in the country-level regressions, we rely on logit models with clustered standard errors and the Beck, Katz, and Tucker (1998) "peace year" correction. Observations with ongoing conflict are excluded.

22. We again provide predicted probabilities calculated while holding all variables at their sample means, whereas the peace years variable is set to 25 and the splines to the corresponding values. In the absence of elections we have a predicted probability of $0.003(S E=0.001)$, which increases by $0.002(0.002)$ in the first competitive election and by $0.003(0.003)$ in the second competitive election.

23. The estimated change in the predicted probabilities of a territorial conflict resulting from elections is $0.002(S E=0.001)$ from a baseline probability of 0.002 ( $S E$ $=0.001)$. The estimated change for governmental conflicts is a minuscule change of $>-0.001(\mathrm{SE}=<0.001)$ from a baseline of $0.001(\mathrm{SE}=<0.001)$.

24. The probability of a territorial conflict increases by $0.003(S E=0.001)$.

25. The predicted change in probability for territorial conflict is $0.005(S E=0.002)$ for the second election and $0.003(S E=0.002)$ for the first election compared to a situation without elections. For governmental conflicts, the respective changes in probabilities are $0.001(S E=<0.001)$ and $-0.001(S E=0.001)$. As with the latter variable, there is a problem of complete separation; these results should not be taken at face value.

26. Birnir (2007) finds that the group's size in the legislature has a negative impact on conflict, which is fully compatible with the results presented here.

\section{References}

Alvarez, R. Michael, Cheibub, Jose Antonio, Limongi, Fernando, \& Przeworski, Adam. (1996). Classifying political regimes. Studies in Comparative International Development, 31, 3-36.

Anderson, Christopher J., \& Mendes, Silvia M. (2005). Learning to lose: Election outcomes, democratic experience and political protest potential. British Journal of Political Science, 36, 91-111.

Beck, Nathaniel, Katz, Jonathan N., \& Tucker, Richard. (1998). Taking time seriously: Time-series-cross-section analysis with a binary dependent variable. American Journal of Political Science, 42, 1260-1288.

Birnir, Jóhanna Kristín. (2007). Ethnicity and electoral politics. Cambridge, UK: Cambridge University Press.

Brancati, Dawn, \& Snyder, Jack L. (2010). Time to kill: The impact of election timing on post-conflict stability. Unpublished manuscript, Washington University in St. Louis and Columbia University, New York, NY.

Brancati, Dawn, \& Snyder, Jack L. (in press). Rushing to the polls: The causes of premature post-conflict elections. Journal of Conflict Resolution.

Bratton, Michael. (1998). Second elections in Africa. Journal of Democracy, 9, 51-66. 
Breton, Albert. (1964). The economics of nationalism. Journal of Political Economy, 72, 376-386.

Buhaug, Halvard. (2006). Relative capability and rebel objective in civil war. Journal of Peace Research, 43, 691-708.

Buhaug, Halvard, Lars-Erik Cederman, and Jan Ketil Rød. (2008). Disaggregating Ethno-Nationalist Civil Wars: A Dyadic Test of Exclusion Theory. International Organization, 62(3), 531-551.

Carothers, Thomas. (2007). The "sequencing" fallacy. Journal of Democracy, 18, $12-27$.

Cederman, Lars-Erik, Hug, Simon, \& Krebs, Lutz. (2010). Democratization and civil war. Journal of Peace Research, 47, 377-394.

Cederman, Lars-Erik, Wimmer, Andreas, \& Min, Brian. (2010). Why do ethnicnationalist groups rebel: New data and analysis. World Politics, 62, 87-119.

Cheibub, Jose Antonio, \& Hays, Jude. (2009, September). Can elections be bad for democracy? Paper presented at the annual meeting of the American Political Science Association, Toronto, Canada.

Collier, Paul. (2009). Wars, guns, and votes: Democracy in dangerous places. New York, NY: Harper.

Collier, Paul, Hoeffler, Anke, \& Söderbom, Måns. (2008). Post-conflict risks. Journal of Peace Research, 45, 461-478.

Dahl, Robert A. (1989). Democracy and its critics. New Haven, CT: Yale University Press.

Dahl, Robert A. (1998). On democracy. New Haven, CT: Yale University Press.

Deutsch, Karl W. (1953). Nationalism and social communication. Cambridge, MA: MIT Press.

Fearon, James D., and David D. Laitin. (2003). Ethnicity, Insurgency, and Civil War. American Political Science Review, 97(1), 75-90.

Flores, Thomas Edward, \& Nooruddin, Irfan. (2010). Electing peace: Do post-conflict elections help or hinder recovery? Fairfax, VA: George Mason University and Ohio State University.

Gleditsch, Kristian Skrede. (2002). All international politics is local: The diffusion of conflict, integration, and democratization. Ann Arbor: University of Michigan Press.

Gleditsch, Nils Petter, Hegre, Håvard, \& Strand, Håvard. (2009). Democracy and civil war. In Manus Midlarsky (Ed.), Handbook of war studies III: The intrastate dimension: Civil strife, ethnic conflict, and genocide (pp. 155-192). Ann Arbor: University of Michigan Press.

Gleditsch, Nils Petter, Wallensteen, Peter, Eriksson, Mikael, Sollenberg, Margareta, \& Strand, Håvard. (2002). Armed conflict 1946-2001: A new dataset. Journal of Peace Research, 39, 615-637. 
Golder, Matt. (2004). Democratic electoral systems around the world, 1946-2000. Electoral Studies, 24, 103-121.

Harbom, Lotta, \& Wallensteen, Peter. (2009). Armed conflicts 1989-2008. Journal of Peace Research, 46, 577-587.

Hegre, Håvard, Ellingsen, Tanja, Gates, Scott, \& Gleditsch, Nils Petter. (2001). Toward a democratic civil peace? Democracy, political change, and civil war, 1816-1992. American Political Science Review, 95, 33-48.

Hegre, Håvard, \& Sambanis, Nicholas. (2006). Sensitivity analysis of empirical results on civil war onset. Journal of Conflict Resolution, 50, 508-535.

Hoddie, Matthew, \& Hartzell, Caroline. (2005). Power sharing in peace settlements: Initiating the transition from civil war. In Philip G. Roeder \& Donald Rothchild (Eds.), Sustainable peace: Power and democracy after civil wars (pp. 83-106). Ithaca, NY: Cornell University Press.

Höglund, Kristin, Jarstad, Anna, \& Söderberg Kovacs, Mimmi. (2009). The predicament of elections in war-torn societies. Democratization, 16, 530-577.

Horowitz, Donald L. (1985). Ethnic groups in conflict. Berkeley: University of California Press.

Huntington, Samuel P. (1968). Political order in changing societies. New Haven, CT: Yale University Press.

Hyde, Susan D., \& Marinov, Nikolay. (2010). National elections across democracy and autocracy: Which elections can be lost? Unpublished manuscript, Yale University, New Haven, CT.

Ivory coast election result overturned. (2010, December 3). Financial Times.

Karl, Terry. (1990). Dilemmas of democratization in Latin America. Comparative Politics, 23, 1-23.

Levitsky, Steven, \& Way, Lucan A. (2002). The rise of competitive authoritarianism. Journal of Democracy, 13, 51-65.

Lindberg, Staffan I. (2009). Democratization by elections: A new mode of transition. Baltimore, MD: Johns Hopkins University Press.

Lust-Okar, Ellen. (2006). State management of political opposition: Lessons from the Middle East. Cambridge, UK: Cambridge University Press.

Manin, Bernard. (1997). The principles of representative government. New York, NY: Cambridge University Press.

Mann, Michael. (2005). The dark side of democracy explaining ethnic cleansing. New York, NY: Cambridge University Press.

Mansfield, Edward D., \& Snyder, Jack. (1995). Democratization and war. Foreign Affairs, 74, 79-97.

Mansfield, Edward D., \& Snyder, Jack. (2005). Electing to fight: Why emerging democracies go to war. Cambridge, MA: MIT Press. 
Mansfield, Edward D., \& Snyder, Jack. (2007a). Democratization and civil war. Unpublished manuscript, University of Pennsylvania and Columbia University, New York, NY.

Mansfield, Edward D., \& Snyder, Jack. (2007b). The sequencing fallacy. Journal of Democracy, 18, 5-9.

Marshall, Monty, \& Cole, Benjamin. (2008, August). A macro-comparative analysis of the problem of factionalism in emerging democracies. Paper presented at the annual meeting of the American Political Science Association, Boston, MA.

Przeworski, Adam. (1991). Democracy and the market. Cambridge, UK: Cambridge University Press.

Rabushka, Alvin, \& Shepsle, Kenneth A. (1972). Politics in plural societies: A theory of democratic instability. Columbus, OH: Merrill.

Rustow, Dankwart A. (1970). Transitions to democracy: Toward a dynamic model. Comparative Politics, 2, 337-363.

Schumpeter, Joseph A. (1942). Capitalism, socialism and democracy. New York, NY: Harper.

Snyder, Jack. (2000). From voting to violence: Democratization and nationalist conflict. New York, NY: Norton.

Strand, Håvard. (2005, January). A theory of democratic elections and armed conflict onset. Paper prepared for the Annual Norwegian Political Science Conference.

Strand, Håvard. (2007). Political regimes and civil war revisited (Unpublished doctoral dissertation). University of Oslo, Oslo, Norway.

Teorell, Jan, Charron, Nicholas, Samanni, Marcus, Holmberg, Sören, \& Rothstein, Bo. (2009). The quality of government dataset, version 17June09. Retrieved from http://www.qog.pol.gu.se

Tomz, Michael, Wittenberg, Jason, \& King, Gary. (2003). Clarify: Software for interpreting and presenting statistical results (Version 2.1). Retrieved from http:// gking.harvard.edu/.

Treier, Shawn, \& Jackman, Simon. (2008). Democracy as a latent variable. American Journal of Political Science, 52, 201-217.

Vreeland, James R. (2008). The effect of political regime on civil war: Unpacking anocracy. Journal of Conflict Resolution, 52, 401-425.

Ward, Michael D., \& Kristian S. Gleditsch. (1998). Democratizing for Peace. American Political Science Review, 92(1), 51-61.

Wimmer, Andreas, Cederman, Lars-Erik, \& Min, Brian. (2009). Ethnic politics and armed conflict: A configurational analysis of a new global data set. American Sociological Review, 74, 316-337.

Zorn, Christopher. (2005). A solution to separation in binary response models. Political Analysis, 13, 157-170. 


\section{Bios}

Lars-Erik Cederman is professor of international conflict research at ETH Zurich. His main interests include computational and spatial modeling of macro-historical processes featuring conflict, including nationalism, state formation, and democratization. He is the author of Emergent Actors in World Politics: How States Develop and Dissolve (1993) and editor of Constructing Europe's Identity: The External Dimension (2001) and coeditor of New Systems Theories of World Politics (2010). His articles have appeared in American Journal of Sociology, American Political Science Review, European Journal of International Relations, International Studies Quarterly, International Organization, Journal of Conflict Resolution, Journal of Peace Research, and World Politics.

Kristian Skrede Gleditsch is professor in the Department of Government, University of Essex and a research associate at the Centre for the Study of Civil War, PRIO. His research interests include conflict and cooperation, democratization, and spatial dimensions of social and political processes. He is the author of All International Politics is Local: The Diffusion of Conflict, Integration, and Democratization (University of Michigan Press, 2002) and Spatial Regression Models (SAGE, 2008) as well as articles in various journals, including American Journal of Political Science, American Political Science Review, Annals of the Association of American Geographers, International Interactions, International Organization, Internasjonal Politikk, International Studies Quarterly, Journal of Conflict Resolution, Journal of Peace Research, Political Analysis, and Political Psychology.

Simon Hug is professor of political science at the University of Geneva (Switzerland) and working group member at the Center for the Study of Civil Wars (CSCW, PRIO). His research interests include the formation of new political parties, the effect of institutions, and more particularly referendums and federalism, on decision making in the national and international arena and conflict resolution, formal theory, and research methods. His publications appear in various journals, among them British Journal of Political Science, Comparative Political Studies, European Journal of Political Research, European Union Politics, International Organization, Journal of Conflict Resolution, Journal of Peace Research, Journal of Theoretical Politics, Legislative Studies Quarterly, Party Politics, Political Analysis, Public Choice, and Review of International Organizations, as well as in several edited volumes and books. 